Acta vet. scand. $1981,22,355-359$.

From the Departments of Pathology and Clinical Chemistry, Faculty of Veterinary Medicine, Swedish University of Agricultural Sciences, and the National Veterinary Institute, Uppsala, Sweden.

\title{
PROGESTERONE IN PREGNANT AND NON-PREGNANT REINDEER
}

\author{
By \\ C. Rehbinder, L.-E. Edquist, U. Riesten-Århed and M. Nordkvist
}

REHBINDER, C., L.-E. EDQVIST, U. RIESTEN-ÅRHED and M. NORDKVIST: Progesterone in pregnant and non-pregnant reindeer. Acta vet. scand. 1981, 22, 355-359. - Peripheral blood plasma levels of progesterone were studied in pregnant and non-pregnant reindeer. Marked differences in progesterone levels were found between pregnant and non-pregnant animals indicating that the determination of progesterone could be used as a pregnancy diagnosis test in reindeer.

reindeer; progesterone; pregnancy diagnosis t e s t.

In reindeer the conception rate, as observed in slaughter material, is found to be higher than the final calving rate (Varo 1964, Skjenneberg \& Slagsvold 1968, Roine 1974). A great variation in calving rate between years is also observed (Skjenneberg \& Slagsvold 1968, Rehbinder 1975). Death of the fetus followed by absorption in early stages of pregnancy, or by abortion in later stages, is reported (Preobrazhenskii 1961, Skjenneberg \& Slagsvold 1968).

In Swedish reindeer herding the number of calves born is controlled each year at the time of calf marking, 4-8 weeks after parturition. The number of dams with calves have been found to vary from year to year, consequently Rehbinder (1975) reported figures ranging from 52 to $98 \%$.

The incidence of intrauterine mortality, abortions, premature births and postnatal deaths is subsequently not known nor are the causes.

To shed further light on embryonic losses a method, which can detect pregnant dams at a given time in a herd of reindeer, is required. Based on available experience from other ruminants 
it was decided to investigate whether the determination of peripheral blood plasma levels of progesterone is a suitable tool for establishing a pregnancy diagnosis test in reindeer.

\section{MATERIAL AND METHODS}

Four female reindeer, 9 years (No. 30), 5 years (No. 29) and 1.5 years (Nos. $31 \& 32$ ), were kept with 5 reindeer bulls in a corral at the National Veterinary Institute, Stockholm. The animals were tagged with heat indicator strips and observed daily for signs of being covered. Blood samples were drawn from the jugular vein twice a week during the breeding period and early pregnancy, every second week during midgestation and during the end of the pregnancy period every second day. The present experiment was undertaken during the time mid September through May.

The blood samples were collected into heparinized tubes and centrifuged. The blood plasma was removed and stored below $-20^{\circ} \mathrm{C}$ until analyses were performed. Progesterone was determined by radioimmunoassay utilizing an antiserum to $11 \alpha-$ hydroxy progesterone (Kindahl et al. 1976). Four ml of dexamethasone ( $9 \alpha$-fluoro-16 $\alpha$-methyl-11 $\beta, 17 \alpha, 21$-trihydroxy-1.4 pregnadiene-3.20-dione, Vorenvet) was administered intramuscularly twice with a 4 day interval to one of the dams (No. 29) around 1 month before estimated time of parturition.

\section{RESULTS}

The peripheral blood plasma levels of progesterone in the 4 reindeer are given in Fig. 1. Animals Nos. 29 and 30 got pregnant while pregnancy was not established in the 2 young animals. The heat mount detectors indicated, however, that all of the animals had been covered several times. In the pregnant animals progesterone levels increased dramatically after breeding and remained high until parturition. The gestation period was 220 days in animal No. 30 while it was 200 days in animal No. 29 which received dexamethasone injections on days 194 and 198 of pregnancy. Progesterone levels remained low throughout the experimental period in the 2 non-pregnant animals Nos. 31 and 32. Occurrence of calvings was manifested through the visualization of fetal membrane and vaginal flow. The calves were not recovered and were in both cases probably taken by fox. 

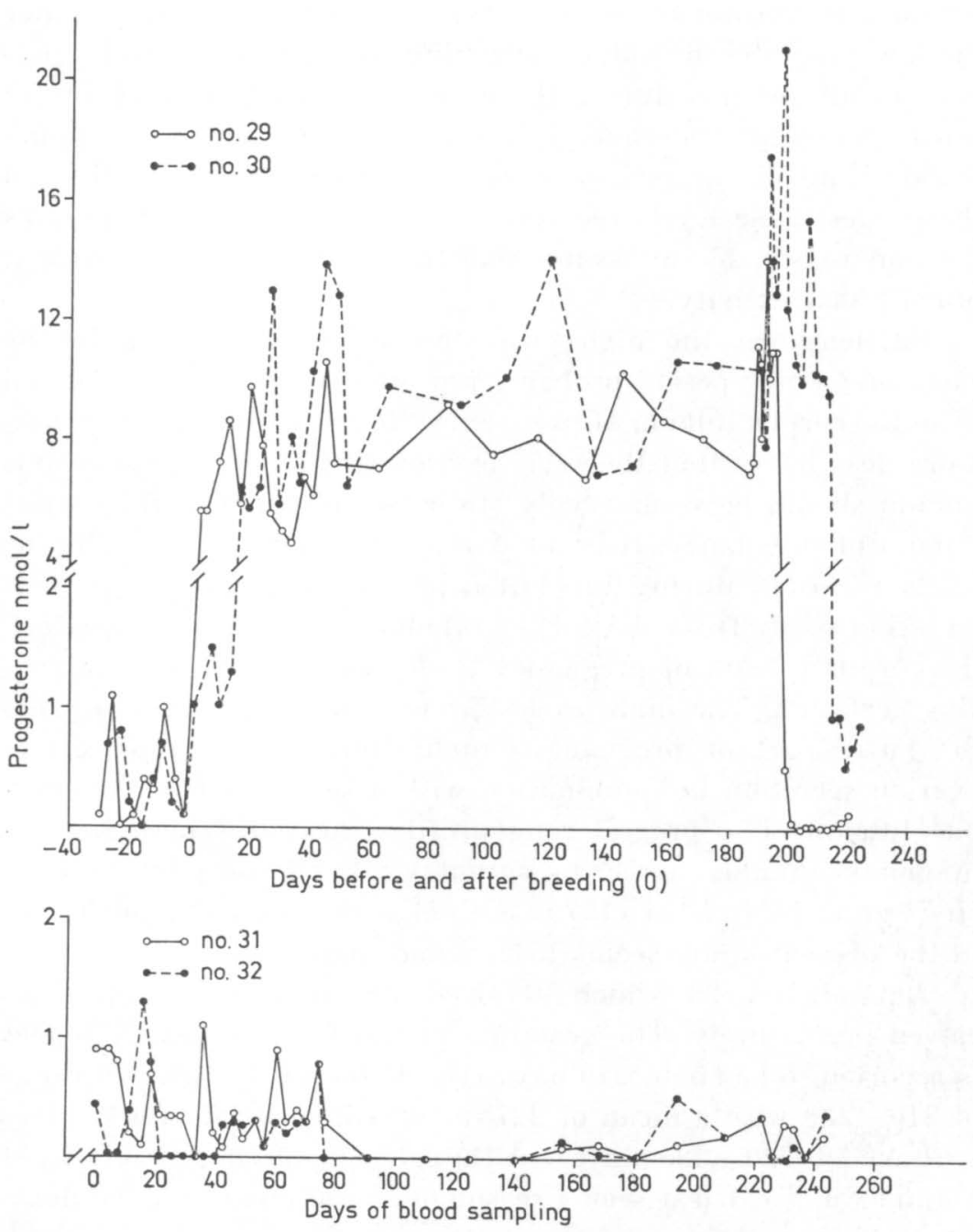

Figure 1. Peripheral blood plasma levels of progesterone in 2 pregnant (above) and 2 non-pregnant (below) reindeer. Animal No. 29 was treated with i.m. injections of dexamethasone on days 194 and 198 of gestation.

\section{DISCUSSION}

The covering date for the 2 pregnant reindeer were judged from the appearance of colouring of the heat mount detectors. This seems, however, to be quite a questionable way of assessing breeding day since the detectors indicated several mountings during the period of high progesterone values in the 2 pregnant 
animals. It can not be assessed from the present study whether the low progesterone values occurring in a relatively cyclic patpern in all animals during the early sampling period represent luteal phase progesterone. When considering the practical detection limit of the progesterone assay (about $0.7 \mathrm{nmol} / \mathrm{l}$ ) and the progesterone levels recorded in the 2 non-pregnant animals it seems reasonable to assume that the patterns do not represent luteal phase activity.

Furthermore, the high progesterone levels recorded in the early pregnancy period probably represent progesterone secreted from the corpus luteum of pregnancy (Roine 1970). It is, furthermore, less likely that the secretory activity of the cyclic corpus luteum should be so markedly lower as compared to the corpus luteum of pregnancy. It is not known whether the progesterone levels recorded during the latter part of pregnancy represent secretion solely from the corpus luteum. Roine (1974) described the corpus luteum of pregnancy to decrease in size with advancing gestation. The high progesterone levels found here, during the latter part of pregnancy, might thus represent an extraovarian secretion in combination with a secretion from the corpus luteum. The progesterone profiles described here for the pregnant animals agree favourably with those published by McEwan \& Whitehead (1979), although the concentration found in the present study seems to be somewhat lower.

Animal No. 29 which received dexamethasone injections calved prematurely. The gestation period for European reindeer is reported to be about 220 days (e.g. Roine (1974) gives a range of 210-238 with a mean of 227 days; Nikolaevskii (1961) gives a range of $220-225$ days). Although considering that only 1 animal was treated it seems reasonable to assume that the dexamethasone injection shortened the gestation period. It is well known from practical reindeer management that excessive stress e.g. through hard driving of herds with late pregnant females may cause abortions. Further studies need to be undertaken on the role of stress during late gestation as a factor contributing to a lowered calving rate.

From the present study it seems obvious that a marked difference of the progesterone levels exists between pregnant and non-pregnant reindeer. The determination of progesterone will thus provide a tool for assessing the overall herd pregnancy status in this species. 


\section{REFERENCES}

Kindahl, H., L.-E. Edqvist, E. Granström \& A. Bane: The release of prostaglandin $F_{2 \alpha}$ as reflected by 15-keto-13,14-dihydroprostaglandin $F_{2 \alpha}$ in the peripheral circulation during normal luteolysis in heifers. Prostaglandins 1976, 11, 871-878.

McEwan, E. H. \& P. E. Whitehead: Plasma progesterone levels during anestrus, estrus and pregnancy in reindeer and caribou (Rangifer tarandus). In Proc. 2nd. Int. Reindeer Caribou Symp. Eds. Reimers, E., E. Gaare \& S. Skjenneberg. Røros, Norway 1979.

Nikolaevskii, L. D.: Diseases of reindeer. In Reindeer Husbandry. Ed. Zhigunow, P. S., Moskva 1961, Israel Program for Scientific Translations.

Preobrazhenskii, B. V.: Management and breeding of reindeer. In Reindeer Husbandry. Ed. Zhigunow, P. S., Moskva 1961, Israel Program for Scientific Translations.

Rehbinder, C.: Kalvdödligheten i Ängeså samebys renhjord. (The calf mortality of the Ängeså reindeer herd). Nord. Vet.-Med. 1975, 27, $241-252$.

Roine, $K .:$ Biometriska iakttagelser om den dräktiga renens genitalorgan. (Biometric studies on the genital organs of the pregnant reindeer). Proc. XIth Nord. Vet. Congr., Bergen 1970.

Roine, $K$.: Studies on the reproduction in female reindeer. Thesis, College of Vet. Med., Helsinki, Finland 1974, 58 pp.

Skjenneberg, S. \& L. Slagsvold: Reindriften og dens naturgrunnlag. (Reindeer Husbandry and its Ecological Principles). Universitetsforlaget, Oslo 1968, $332 \mathrm{pp}$.

Varo, M.: Tutkimuksia poron jalostusmahdollisuursista. (Investigations on the possibilities of reindeer breeding). Ann. Agric. Fenn. $1964,3,296-310$.

\section{SAMMANFATTNING}

Progesteron hos dräktiga och icke dräktiga renar.

Blodplasmanivån av progesteron hos dräktiga och icke dräktiga renar undersöktes. Stora skillnader i progesteronnivåer förelåg mellan dräktiga och icke dräktiga djur. Analys av progesteron kan således användas för att fastställa dräktighet hos ren.

(Received May 11, 1981).

Reprints may be requested from: C. Rehbinder, the Department of Pathology, College of Veterinary Medicine, Swedish University of Agricultural Sciences, S-750 07 Uppsala, Sweden. 